Int. J. Electrochem. Sci., 15 (2020) $6024-6034$

International Journal of

ELECTROCHEMICAL

SCIENCE

$\underline{\text { www.electrochemsci.org }}$

\title{
Preparation and Electrochemical Performance of Manganese- Doped Nickel Hydroxide Cathode Materials
}

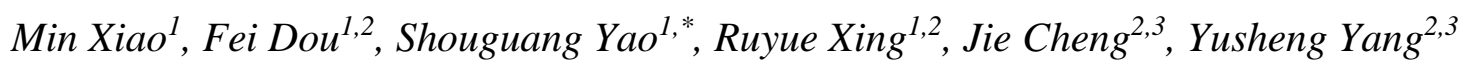 \\ ${ }^{1}$ School of Energy and Power Engineering, Jiangsu University of Science and Technology, Zhenjaing, \\ Jiangsu 212003, China \\ ${ }^{2}$ Zhangjiagang Smartgrid Fanghua electrical energy storage research institute Co. Ltd., Zhangjiagang \\ 215600, China \\ ${ }^{3}$ Chilwee Power Co., Ltd., Huzhou 313100, China \\ *E-mail: zjyaosg@126.com
}

doi: $10.20964 / 2020.07 .63$

Received: 3 March 2020 / Accepted: 8 May 2020 / Published: 10 June 2020

Buffer solution method can maintain the stability of $\mathrm{pH}$ in the reaction process, so that the physical and chemical properties of the product are good. Manganese-doped $\mathrm{Ni}_{1-x} \mathrm{Mn}_{x}(\mathrm{OH})_{2}(x=0.15,0.18,0.22,0.25)$ was prepared by buffer solution method. X-ray diffraction measurements showed that the samples were mainly composed of $\beta-\mathrm{Ni}(\mathrm{OH})_{2}$, and some of the Mn-doped samples contain a small amount of impurities. Scanning electron microscopy measurements showed that the crystal particles of Mn-doped samples were small. The specific surface area measurements results showed that the BET surface area of Mn-doped samples were more and the Mn-doped samples had mesoporous structures. Cyclic voltammetry results showed that the difference between the oxidation peak potential and the reduction peak potential of the Mn-doped samples was small. The Mn-doped samples demonstrated better electrochemical performance than commercial $\beta-\mathrm{Ni}(\mathrm{OH})_{2}$. Constant current charge-discharge results showed that samples with an Mn content of $18 \mathrm{~mol} \%$ yielded the highest discharge specific capacity, the best cycle stability with discharge specific capacity of $314.5 \mathrm{mAh} \mathrm{g}^{-1}$ at $800 \mathrm{~mA} \mathrm{~g}^{-1}$, while the discharge specific capacity of commercial $\beta$ - $\mathrm{Ni}(\mathrm{OH})_{2}$ was $195 \mathrm{mAh} \cdot \mathrm{g}^{-1}$. It shows that $\mathrm{Mn}$ doping can improve the discharge specific capacity of the positive electrode and make the battery have good charge and discharge performance at high current. When the sample with Mn content of $18 \mathrm{~mol} \%$ was cycled at 800 $\mathrm{mA} \cdot \mathrm{g}^{-1}$ for 30 cycles, the discharge specific capacity did not decrease, while other samples containing $\mathrm{Mn}$ and commercial $\beta-\mathrm{Ni}(\mathrm{OH})_{2}$ showed different degrees of discharge specific capacity. As a positive electrode material, $\mathrm{Ni}_{0.82} \mathrm{Mn}_{0.18}(\mathrm{OH})_{2}$ has good cycle stability. A series of experimental results have proved that a proper amount of Mn doping $(18 \mathrm{~mol} \%)$ can effectively improve the electrochemical performance of nickel electrodes and reduce the cost of cathode materials.

Keywords: Buffer solution method; Mn-doped $\mathrm{Ni}(\mathrm{OH})_{2}$; Rate capability; Cyclic stability 


\section{FULL TEXT}

(C) 2020 The Authors. Published by ESG (www.electrochemsci.org). This article is an open access article distributed under the terms and conditions of the Creative Commons Attribution license (http://creativecommons.org/licenses/by/4.0/). 